\title{
PROJEKTOVÝ MANAŽMENT S VYUŽITÍM METÓD PRINCE2
}

\author{
L'ubomír Bombala*
}

\section{Úvod}

Väčšina firiem sa v súčasných trhových podmienkach snaží nachádzat' spôsoby ako zvyšovat' efektivitu podnikania, čiže maximalizovat' zisk a trhový podiel. Firmy sú si vedomé, že stále sa meniace trhové, finančné, zákonné a i. požiadavky, neumožňujú počítat' s konštantami, ktoré by im ul'ahčili rozhodovanie a zmenšili frekvenciu zmien. V tejto súvislosti manažéri radi hovoria, že jedinou konštantou v podnikaní je zmena. Dnešné firmy musia počítat' s vel'kým množstvom zmien, musia zmeny brat' ako nevyhnutnost' a prirodzenú súčast' života firmy. Úspešné firmy sú potom tie, ktoré sa vedia so zmenami lepšie vyrovnat', resp. vedia zmeny lepšie manažovat'. Ked’že zmeny sú nevyhnutné a vyžadujú si organizáciu, siahajú firmy po overených spôsoboch riadenia. V súčasnosti sa za takýto spôsob považuje organizácia práce do projektov. Firmy siahajú po moderných a overených metódach projektového manažmentu, ktoré prostredníctvom skúseností odborníkov organizujú zmenu podl'a štandardizovaného a definovaného postupu. V tejto súvislosti je projekt možno definovat' ako riadené prostredie vytvorené za účelom poskytnutia jedného alebo viacerých produktov podnikania na základe špecifického podnikatel'ského zámeru [1]. Iná definícia označuje projekt ako dočasnú organizáciu, ktorá je potrebná na vytvorenie unikátnych a preddefinovaných výsledkov za dopredu daný čas využitím vopred determinovaných zdrojov [1].

Projekty spájajú dokopy zdroje, poznatky, technológie a myšlienky, aby splnili požadované ciele a priniesli požadovaný prínos. Projektové riadenie pomáha zaistit', že riziká sú identifikované a správne manažované, ciele a prínos sú dosiahnuté v rámci rozpočtu, $\mathrm{v}$ rámci stanoveného času a v požadovanej kvalite.

Ciel'om tohto príspevku je poskytnút' základnú informáciu o procesoch, komponentoch a technikách, ktoré využíva PRINCE2 metóda. Podrobné informácie o metóde nájdeme v [1].

\section{Prečo využívat’ metódu pri projektovom manažmente?}

Neúspešné projekty majú často vel’a spoločného, niekedy si príčinu neúspechu zapamätáme, inokedy na ňu rýchlo zabudneme. Tvorcovia PRINCE2 sú si vedomí množstva rozličných dôvodov, pre ktoré boli projekty neúspešné. Bez existencie metódy budú mat' tvorcovia projektu, manažéri a tí čo sa na ňom podiel'ajú odlišné predstavy o jeho organizácii a o tom,

\footnotetext{
* Ing. L’ubomír Bombala, DHL IT Services Europe, V Parku 2308/10, 14800 Praha 4, ext. doktorand, Katedra spojov, FPEDAS, ŽU v Žiline

tel: +420288802185

e-mail: lubomir.bombala@dhl.com
} 
kedy sa majú dokončit' príslušné fázy projektu. Bolo by problémom identifikovat' úlohy, zodpovednosti a právomoci jednotlivých členov tímu, bez ktorých by v projekte panovali nejasnosti. Toto je dôležité pri vel'kých projektoch, ktoré by sa bez metódy nedali uskutočnit' načas a $\mathrm{v}$ rámci rozpočtu.

PRINCE2 stavia na princípoch projektového manažmentu, ktoré sú:

- Projekt je konečný proces s definovaným začiatkom a koncom

- Projekt musí byt' manažovaný, aby mohol byt' úspešný

- Pre skutočné odovzdanie sa projektu musí byt' všetkým zúčastneným stranám jasné, prečo je projekt potrebný, čo sa má projektom dosiahnut', aké výstupy sa majú dosiahnut' a aké sú ich úlohy pri ich dosiahnutí

\section{PRINCE2}

PRINCE2 je považovaný za medzinárodný produkt s celosvetovou aplikáciou a štandardnú metódu pre projektový manažment. Spája v sebe dlhoročné skúsenosti mnohých odborníkov a poskytuje flexibilný prístup vd'aka čomu sa hodí na všetky typy projektov. Dôraz je v PRINCE2 kladený na tzv. business case (podnikatel'ský prípad), ktorý je zvyčajne špecifikovaný vrcholovým manažmentom firmy. Business case obsahuje logické a podnikatel'ské zdôvodnenie projektu, ktoré determinuje všetky projektové procesy od inicializácie až po úspešné ukončenie. Ak by počas projektu stratil business case svoje opodstatnenie, znamenalo by to aj ukončenie projektu.

Mechanizmy PRINCE2 umožňujú efektívne skombinovat' externé a interné zdroje, ako napríklad prácu externých firiem a vlastných zamestnancov.

PRINCE (PRojects IN Controlled Environments) ako metóda bola prvý raz definovaná v roku 1989 agentúrou CCTA. PRINCE bol vyvinutý z PROMPTII, čo je metóda projektového manažmentu vytvorená Simpact Systems Ltd v roku 1975. PROMPTII bol prijatý agentúrou CCTA v roku 1979 ako štandard používaný pre projekty vládnych informačných systémov. Bol nahradený PRINCE v roku 1989 v rámci vládnych projektov.

CCTA (v súčasnosti Office of Government Commerce) pokračoval vo vývoji metódy a v roku 1996 predstavil PRINCE2. Jeho hlavnou výhodou oproti PRINCE je jeho orientácia na všetky typy projektov, nie iba informačných systémov.

\section{Prínosy využitia metód PRINCE2}

PRINCE2 je prínosom pre všetky strany zainteresované na projekte a pre organizácie ako celok. Z hl'adiska prínosov pre projekt možno spomenút':

- Poskytuje organizovaný a riadený začiatok, priebeh i ukončenie

- Pravidelné kontroly postupu vzhl'adom k plánu a vzhl'adom na business case

- Flexibilné body rozhodnutia

- Automatické riadenie odchýlok od plánu

- Zaangažovanost' manažmentu a zúčastnených strán na dodržiavaní termínov počas projektu

- Dobré komunikačné kanály medzi tímom projektového manažmentu a zvyškom organizácie

- Dohoda na požadovanej kvalite na začiatku a priebežné monitorovanie vzhl'adom na stanovené požiadavky

\section{Definície}


Pre potreby tohto článku je potrebné uviest' niektoré pojmy z terminológie metódy PRINCE2 [1]. Vyhneme sa takto neskorším nejasnostiam.

Business case (podnikatel'ský prípad) definuje informáciu, ktorá objasňuje nastavenie, pokračovanie a ukončenie projektu. Zdôvodňuje samotnú existenciu projektu a je aktualizovaný v kl'účových momentoch projektu.

Customer (zákazník) reprezentuje skupinu alebo osobu, ktorá si objednala prácu a výsledky projektu budú pre ňu prínosom.

Product (produkt) znamená všetko čo má projekt vytvorit' alebo zmenit', pričom sa môže jednat' aj o nehmotné veci ako je kultúrna zmena a verejná mienka.

Programme (program) predstavuje súbor projektov, ktoré spolu vytvárajú zmenu, ktorá je prínosom pre celú organizáciu.

Supplier (dodávatel') predstavuje skupinu, ktorá je zdrojom špecialistov a poznatkov pre projekt alebo poskytuje statky a služby na vytvorenie výstupu požadovaného zákazníkom resp. užívatel'om.

User (zákazník - užívatel') definuje osobu alebo skupinu, ktorá bude využívat' konečný produkt. V niektorých prípadoch je customer a user tá istá skupina l'udí.

\section{Charakteristiky PRINCE2 projektu}

K základným charakteristikám PRINCE2 projektu patrí:

- Konečný a definovaný životný cyklus

- Definované a meratel'né produkty podnikania

- Korešpondujúca sada aktivít na docielenie produktov podnikania

- Definované množstvo zdrojov

- Organizačná štruktúra s definovanými zodpovednost’ami za manažovanie projektu

Zámerom PRINCE2 nie je obsiahnut' všetky aspekty spojené s projektovým manažmentom, preto niektoré nástroje a techniky sa budú rôznit' podl'a typu projektu a prostredia organizácie. Niektoré aspekty sú dobre popísané existujúcimi a overenými metódami, a preto ich PRINCE2 neobsahuje ako napr.:

- Techniky manažmentu l’udských zdrojov ako motivácia, delegovanie a vedenie tímu

- Kontrola rozpočtu a techniky analýzy pridanej hodnoty

- Vytvorenie a manažment kvality organizácie a takisto techniky zabezpečovania a zlepšovania kvality

- Plánovacie techniky ako Ganttove diagramy

Hoci PRINCE2 neobsahuje dané metódy, dokáže si s nimi vel'mi efektívne vymieňat' informácie, ktoré si vyžaduje samotný projektový manažment. Projektový manažment s využitím PRINCE2 začína skôr ako projekt, pripravuje základy, aby projekt mohol začat' organizovaným a kontrolovaným spôsobom.

\section{Procesný model PRINCE2}

PRINCE2 využíva procesný prístup k projektovému manažmentu. Procesy definujú aktivity, ktoré je potrebné vykonat' počas projektu. Okrem toho popisuje PRINCE2 komponenty, ktoré sú aplikované $\mathrm{v}$ rámci príslušných aktivít. V rámci PRINCE2 je definovaných 8 komponentov. Na obr. 1 je znázornený procesný model PRINCE2, ktorý pozostáva z 8 rozličných procesov, ktoré sú d'alej členené na podprocesy. Zahŕňa aktivity od nastavenia projektu, cez kontrolu a manažment jeho priebehu až po jeho ukončenie. Spoločný proces plánovania (Planning) je využívaný 4 d’alšími procesmi. 
Každý projekt realizovaný s využitím metódy PRINCE2 využíva všetkých 8 procesov do určitej miery, ktorá je určená individuálnymi požiadavkami na projekt.

PRINCE2 ponúka iba 3 techniky a necháva výber techník na používatel'a metódy a na okolností projektu.

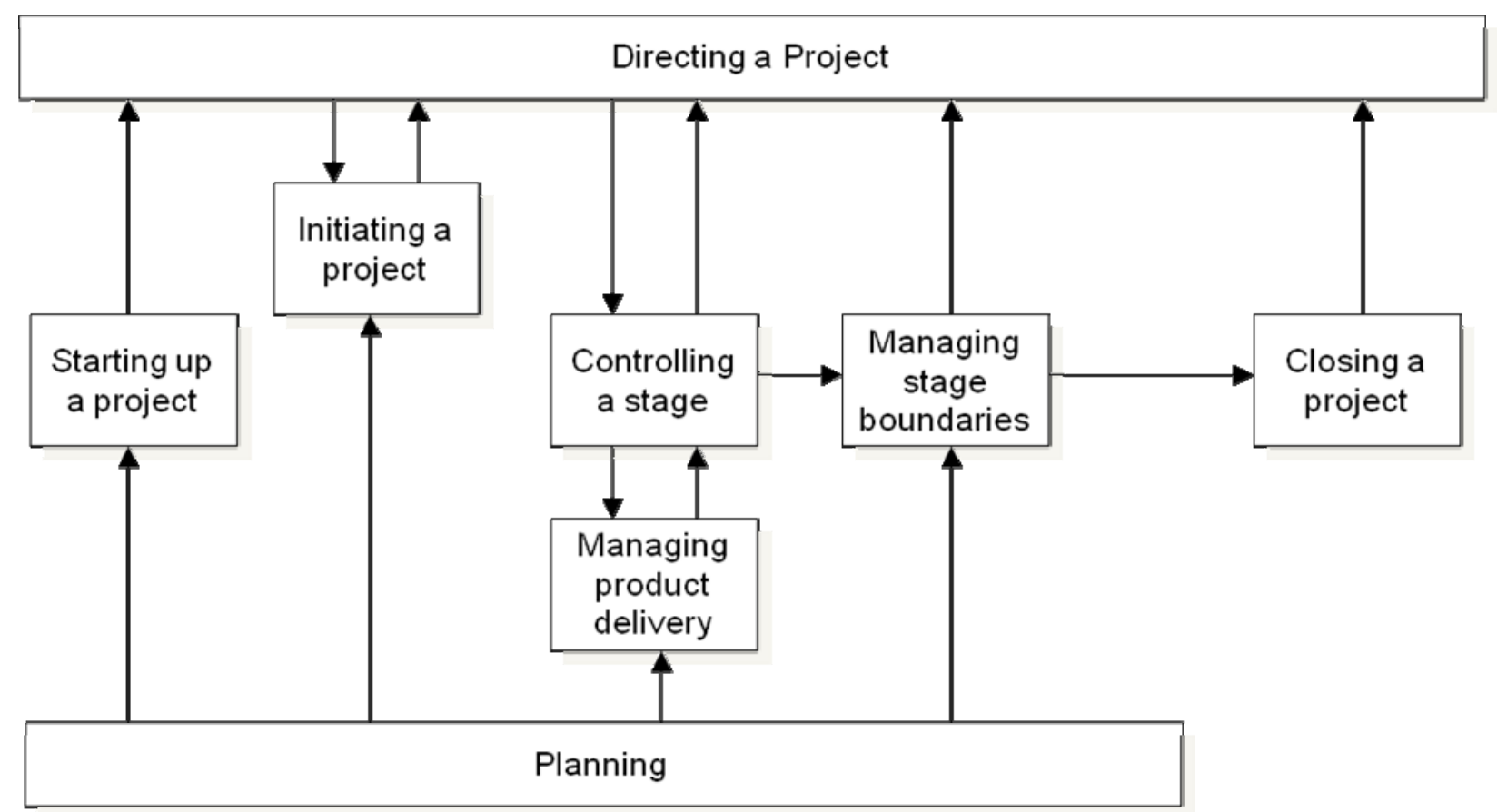

Obr.1.: Procesný model PRINCE2

\section{Procesy PRINCE2}

Projekt PRINCE2 pozostáva z 8 procesov a ich podprocesov, ktoré môžeme stručne popísat'.

Rozbehnutie projektu (Starting up a Project)

Tento proces je pryým procesom v PRINCE2 a zaist'uje splnenie prerekvizít pre proces Initiating a Project a d’alšie procesy. Proces je spustený obdržaním Projektového mandátu, ktorý popisuje dôvody pre projekt a finálny produkt. Počas tohto procesu je potrebné ustanovit' nasledovné:

- tím projektového manažmentu a ak to je možné, zorganizovat' jeho stretnutie

- Project Brief (definuje čo, kto, prečo, ako a kedy pre projekt)

- Project Approach t.j. všeobecný popis toho, ako bude vypadat' riešenie

- Očakávania zákazníka ohl'adne kvality

- Risk log, ktorý zaznamenáva identifikované riziká, ich analýzu a status

- The Initiation Stage Plan (Plán inicializačnej etapy)

Pre projektového manažéra sa vytvorí tzv. daily log, ktorý sa bude využívat' počas celého projektu. Sú to jeho poznámky, ktoré mu pomôžu pri riadení projektu.

Iniciovanie projektu (Initiating a Project)

Ciel'om toho procesu je:

- Definovanie, ako bude dosiahnutá požadovaná kvalita produktu

- Plánovanie projektu a náklady 
- Úprava podnikatel'ského prípadu a potvrdenie, že je akceptovatel'ný pre realizovanie projektu

- Uistenie sa o oprávnenosti investovaného času a úsilia vyžadovaného projektom, zohl'adnenie rizík projektu

- Prevzatie vlastníctva projektu projektovou radou a súhlas s alokáciou zdrojov pre d’alšiu etapu

Klúčovým produktom tohto procesu je Project Initiation Document (PID), ktorý definuje čo, prečo, kto, kedy a ako pre projekt vykoná.

Počas tohto procesu sa vytvoria aj tri prázdne dokumenty: The Quality Log - záznam o kontrolách kvality, The Issue Log - určený pre zaznamenanie problémov, The Lessons Learned Log - $\log$ poznatkov a skúseností použitel'ný pre d’alšie projekty.

Tieto dokumenty sa budú vypíňat' v d'alších etapách projektu.

\section{Riadenie projektu (Directing a Project)}

Tento proces prebieha od rozbehnutia projektu až po jeho ukončenie. Vykonáva ho projektová rada, ako skupina manažérov reprezentujúcich samotnú firmu, zákazníkov aj dodávatel'ov. Projektová rada manažuje, monitoruje prostredníctvom reportov a riadi prostredníctvom určitých rozhodovacích okamihov. Medzi 5 kl'účových procesov pre projektovú radu zarad'ujeme tieto oblasti:

- Autorizovanie inicializácie

- Autorizovanie projektu - je spojené s kontrolou PID

- Hranice etáp (schválenie d’alších zdrojov)

- Ad hoc riadenie (monitorovanie progresu, poskytovanie rád a vedenie, reagovanie na významné problémy, ktoré sa týkajú plánov alebo prínosu)

- Ukončenie projektu (potvrdenie výstupov projektu a riadené ukončenie projektu)

Plánovanie (Planning)

Plánovanie je opakujúci sa proces a zohráva dôležitú úlohu v ostatných procesoch, medzi hlavné patrí:

- Plánovanie inicializačnej etapy

- Plánovanie projektu

- Plánovanie etapy

- Aktualizovanie projektového plánu

- Akceptovanie work package (séria informácií o produkte pre tímového manažéra)

- Vytvorenie plánu pre prípad výnimiek

Nezávisle od plánu proces vytvára:

- Product checklist, čo je zoznam produktov, ktoré majú byt' vytvorené plánovanou prácou, ktorý obsahuje plánované a aktuálne dátumy dodania produktov

- Risk log, aktualizovaný zmenami vyplývajúcimi z procesu plánovania

Riadenie etapy (Controlling a Stage)

Tento proces popisuje monitorovacie a riadiace činnosti projektového manažéra spojené $\mathrm{s}$ alokáciou práce, zaistením, že sa etapa vyvíja podl'a plánu a reagovaním na neočakávané deje. Riadenie etapy je jadrom práce projektového manažéra na projekte, pretože riadi projekt na dennej báze. V priebehu etapy sa potom vyskytuje opakovane: autorizovanie práce, zbieranie informácií o progrese $\mathrm{v}$ práci, sledovanie zmien, kontrola situácie, reportovanie a korekčné činnosti.

Produkty vytvorené na cyklickej báze počas etapy sú:

- Work packages 
- Highlight Reports, pravidelné reporty o progrese projektu vytvárané projektovým manažérom pre Project Board

- Project issues čiže problémy s projektom (a aktualizovaný Issue Log)

- Aktualizovaný Risk Log

- Pravidelne aktualizovaný plán etapy

Niekedy je potrebné vytvorit' aj Exception Report, čiže správu o výnimkách počas etapy.

Manažovanie dodania produktu (Managing Product Delivery)

Ciel'om tohto procesu je zaistit', aby plánované produkty boli vytvorené a dodané projektom, čo predstavuje nasledovné činnosti:

- Manažér tímu dohodne detaily work packages s projektovým manažérom

- Uistenie sa, že práca na produktoch alokovaná tímom je autorizovaná a schválená

- Zaistenie, že práca sa podriad'uje požiadavkám interfejsov definovaných v work package

- Zaistenie, že práca je vykonaná

- Pravidelné hodnotenie priebehu prác a prognózovanie

- Zaistenie, že finálne produkty spíňajú kritériá kvality

- Schválenie hotových produktov

Počas tohto procesu sú vytvorené a aktualizované nasledovné produkty:

- Tímové plány

- Aktualizácie quality logu, dávajúce projektovému manažérovi prehl'ad o kvalite práce

- Project issues čiže projektové problémy

- Aktualizácie risk logu

- Checkpoint reports, pravidelné správy o progrese od tím manažéra pre projektového manažéra

Manažovanie rozhraní etáp (Managing Stage Boundaries)

Tento proces vytvára informáciu pre Project Board. Na základe tejto informácie sa potom Project Board rozhodne či pokračovat's projektom alebo nie.

Ciel'om tohto procesu je:

- Uistit' Project Board o tom, že všetky produkty plánované v súčasnej etape boli dokončené podl'a plánu

- Poskytnút' informáciu pre Project Board, aby mohol zhodnotit' životaschopnost' projektu

- Poskytnút' d’alšie informácie pre Project Board, ktoré sú potrebné na schválenie dokončenia aktuálnej etapy a autorizovanie štartu d'alšej etapy

- Zaznamenat' merania a poznatky, ktoré môžu pomôct' v d'alších etapách projektu alebo v d'alších projektoch

Produktmi tohto procesu sú:

- Report o ukončení etapy, podáva projektový manažér projektovej rade, obsahuje informáciu o tom, čo sa v danej etape dosiahlo

- Porovnanie aktuálneho plánu etapy s pôvodným plánom etapy

- Plán d’alšej etapy a plán výnimiek, ktoré je potrebné schválit'

- Revidovaný plán projektu

- Aktualizovaný Risk log, ktorý je spolu s podnikatel'ským prípadom a projektovým plánom použitý projektovou radou na zhodnotenie životaschopnosti projektu

- Aktualizovaný podnikatel'ský prípad

- Lesson Learned Log, aktualizovaný o poznatky z aktuálnej etapy

- Zmeny v štruktúre a zložení tímu projektového manažmentu 
- V príprave na d’alšiu etapu je možné vytvorit’ aj plány práce pre jednotlivé tímy

Ukončenie projektu (Closing a Project)

Ciel'om tohto procesu je vykonat' riadené ukončenie projektu. Proces znamená prácu manažéra na konci projektu alebo pri jeho predčasnom ukončení. Väčšinu práce predstavuje príprava vstupov pre projektovú radu, ktorá na základe nich potvrdí, že projekt sa môže ukončit'.

Ciele ukončenia projektu sú preto:

- Skontrolovat' mieru plnenia ciel'ov stanovených v PID

- Zhodnotit', do akej miery boli všetky očakávané produkty dodané a akceptované zákazníkom

- Potvrdit', že údržba a operačné usporiadanie (kde je to potrebné) vrátane potrebného školenia

- Navrhnút' odporučenie pre budúce projekty

- Zhromaždit' znalosti z projektu a dokončit' Lessons Learned Report

- Pripravit' Report ukončenia projektu

- Archivácia projektových súborov

- Vytvorenie Post-Project Review Plan, jeho úlohou je posúdenie, či produkty projektu priniesli očakávaný prínos po určitej dobe od ukončenia projektu.

- Odporučenie projektovej rade, aby rozpustila projektovú organizáciu a uvol'nil zdroje

\section{Komponenty PRINCE2}

V projektovom riadení sú komponenty rozhodujúcimi článkami. PRINCE2 má 8 komponentov:

Podnikatel'ský prípad (Business case)

Podl'a metodiky PRINCE2 je to riadiaca podmienka projektu. Projektová rada ho verifikuje pred začiatkom projektu a pri každom dôležitom rozhodnutí počas projektu.

Organizácia (Organisation)

Predstavuje štruktúru tímu projektového manažmentu a definíciu zodpovedností a vzt'ahov jednotlivých členov tímu. Podl'a vel'kosti projektu sa môžu niektoré funkcie kombinovat' alebo zdiel'at'.

Plány (Plans)

PRINCE2 ponúka niekol'ko stupňov plánovania, ktoré je potrebné prispôsobit' vel'kosti a potrebám projektu.

Regulačné prvky (Controls)

PRINCE2 ponúka súbor riadiacich prvkov, ktoré poskytujú informácie pre tvorbu rozhodnutí a umožňujú predchádzat' problémom a robit' rozhodnutia na riešenie problémov.

Manažment rizika (Management of risk)

Riziká sú významné faktory, ktoré musíme zohl'adnit' počas projektu. PRINCE2 definuje kl'účové momenty, kedy sa majú riziká posúdit', naznačuje prístup $\mathrm{k}$ analýze a manažmentu rizika a vedie ho cez všetky procesy.

Kvalita v projektovom prostredí (Quality in a project environment)

Znamená dôraz na kvalitu vo všetkých procesoch a v manažmente PRINCE2 projektu. Začína sa zistením očakávaní zákazníka ohl'adne kvality, pokračuje stanovením štandardov a metód kontroly kvality a samozrejme kontrolou ich používania.

Manažment konfigurácie (Configuration management)

Predstavuje značenie a sledovanie komponentov konečného produktu a ich verzií pre vydanie.

Riadenie zmien (Change control) 
Potreba riadenia zmien je v PRINCE2 natol'ko dôležitá, že je spojená s technikou riadenia zmien.

\section{Techniky PRINCE2}

Produktovo-orientované plánovanie (Product - based planning - PBP)

Táto technika poskytuje rozhranie založené na produktoch, ktoré môže byt' aplikované na akýkol'vek projekt. Použitím tejto techniky vznikajú štyri produkty:

1. Popis konečného produktu projektu

2. Hierarchická štruktúra produktu (Product Breakdown Structure - PBS)

3. Popisy každého z produktov, ktoré vznikli z PBS

4. Diagram produktových tokov (Product Flow Diagram - PFD)

Riadenie zmien (Change control)

Každý projekt si vyžaduje techniku riadenia zmien. Pre organizácie, ktoré nemajú vhodnú techniku, ponúka PRINCE2 vlastnú techniku.

Revizie kvality (Quality reviews)

Táto technika je čiastočne vhodná na testovanie produktov, ktoré sú zdokumentované, hoci jej princípy sa dajú aplikovat' na akúkol'vek formu testovania kvality a revízie.

\section{Organizačná štruktúra projektového manažmentu podl’a PRINCE2}

Organizačná štruktúra PRINCE2 je založená na prostredí zákazník/dodávatel' a možno ju znázornit' schémou na obr. 2.

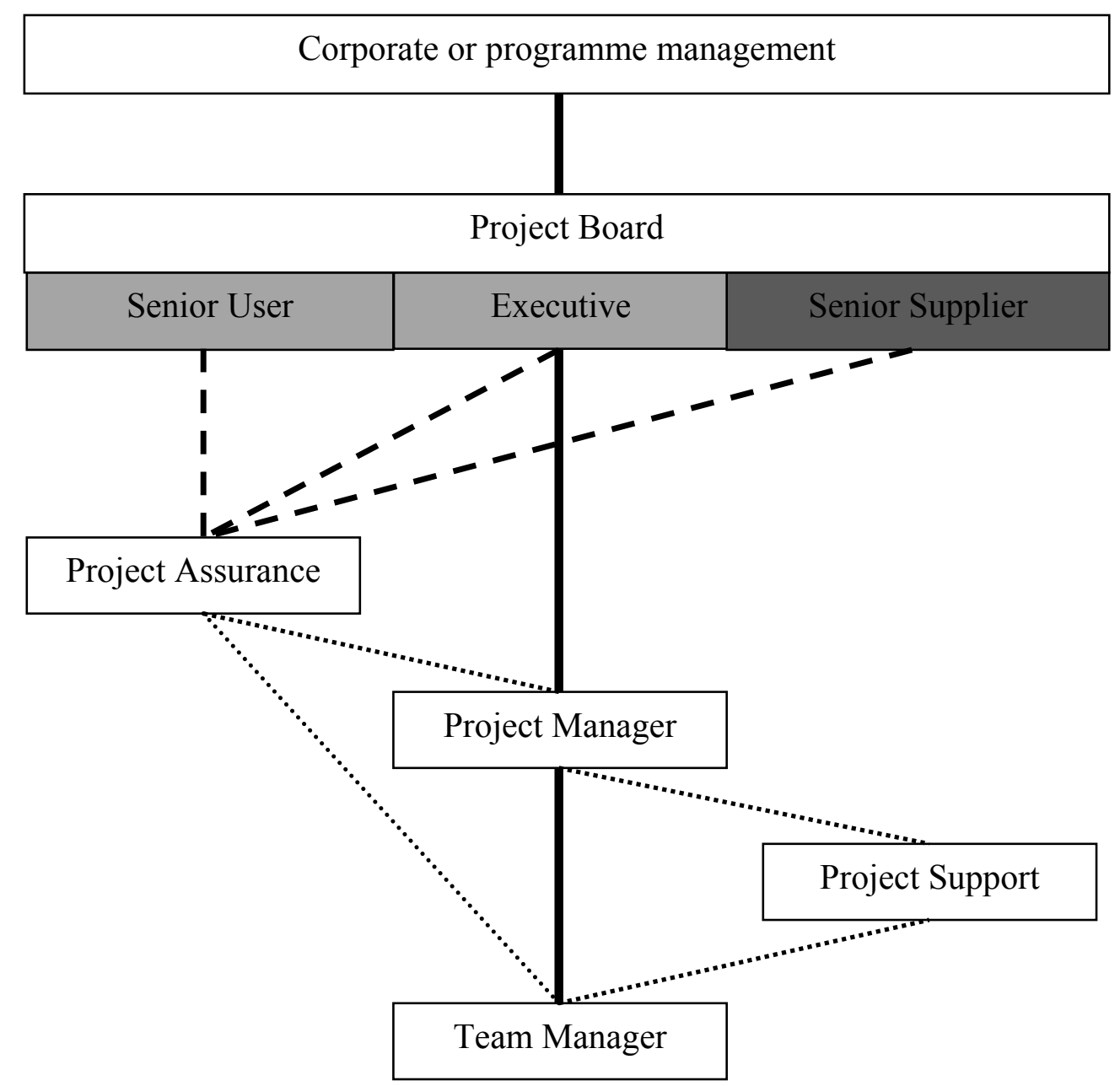




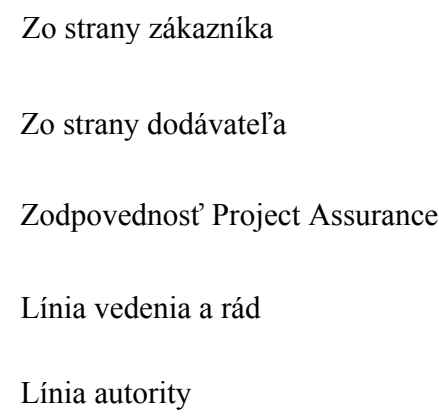

Obr.2.: Organizačná štruktúra projektového manažmentu

Fundamentálnym princípom PRINCE2 je, že manažment projektu má 4 vrstvy. Najvyššiu predstavuje korporátny alebo programový manažment (Corporate or programme management) t.j. manažment celej organizácie alebo súboru projektov. Druhú vrstvu predstavuje projektová rada (Project Board), ktorá riadi projekt, pričom ju tvoria zástupcovia zo strany zákazníka, tí čo budú využívat' konečný produkt (Senior User), Executive, ktorý zastupuje záujmy zákazníka projektu, čiže záujmy podnikania, pričom je zodpovedný za projekt a dodávatel'a (Senior Supplier), ktorý poskytne poznatky pre projekt. Tretiu úroveň predstavuje Project manager, ktorý riadi projekt na dennej báze, má presne dané zodpovednosti a právomoci, pričom sa zodpovedá projektovej rade. Najnižšiu úroveň prestavuje Team manager, t.j. manažér jednotlivých tímov, ktoré vytvárajú jednotlivé produkty. Dôležitú úlohu zohráva aj Project Assurance, čo je delegát projektovej rady, ktorý ponúka informácie o projekte nezávisle od projektového manažéra, súčasne môže vykonávat' niektoré z funkcií projektovej rady. Project Support poskytuje administratívnu podporu pre projektového manažéra, pričom môže vykonávat' aj poradenskú činnost'.

\section{Záver}

Účelom príspevku bolo priblížit' a zoznámit’ čitatel'a so základnými princípmi metódy PRINCE2. Jej výber nie je náhodný, pretože je to v najpoužívanejšia metóda v Európe, využívajú ju také firmy ako DHL, Deutsche Post World Net, Logica CMG, Accenture, Sun Microsystems a d’alšie. V priebehu roku 2009 bude vydaná aktualizácia metódy PRINCE2.

Samozrejme PRINCE2 nie je jedinou metódou pre projektový manažment. Ďalšími metódami sú PMBOK (A Guide to the Project Management Body of Knowledge), ktorú vytvoril PMI (Project management institute). V Európe bola vytvorená organizácia International Project Management Association (IPMA), ktorá je akousi obdobou PMI. Táto organizácia vytvorila IPMA Competence Baseline (ICB). Svoje štandardy pre projektový manažment vytvorila aj International Organization for Standardization, a to štandard ISO 10006 Quality management systems - Guidelines for quality management in projects. Tento štandard nie je príručkou pre projektový manažment, ale popisuje kvalitu v projektovom manažmente. ISO pripravuje komplexný štandard ISO 21500 Project Management - Guide to the Project Management, ktorý by mal byt' publikovaný v roku 2010. Organizácie PMI a IPMA sa podiel'ajú na prácach na ISO 21500. Okrem spomenutých metód existujú d'alšie národné či odvetvové štandardy a modely. 


\section{Literatúra}

[1] Office of Government Commerce: Managing Successful Projects with PRINCE2, TSO, London, 2005

[2] PearceMayfield: Prince2 Foundation Course, 2006

[3] http://www.pmichaptersaustralia.org.au/canberra/Documents/ISO 21500 Communique No1.pdf

[4] http://www.pm4success.com

[5] http://www.ogc.gov.uk/delivery lifecycle_project_management.asp

[6] http://www.ipma.ch 